\title{
Anti-angiogenesis and apoptogenic potential of the brown marine alga, Chnoospora minima
}

\author{
Shabana Parveen and Varalakshmi K. Nadumane* (D)
}

\begin{abstract}
Background: Algae being one of the dominant organisms in nature can provide best opportunity for the discovery of new anti-cancer drugs. The aim of the present study was to investigate the anti-cancer and anti-angiogenic potential of the brown marine alga Chnoospora minima.

Result: The methanol extract of C. minima and its bioactive fraction (CF4) have highly significant cytotoxic effects to HepG2, HeLa and MCF-7 cancer cell lines. The fraction's ability to induce apoptosis in the cancer cells was evidenced by increased caspase activity (caspase-3, 7 and 10), DNA fragmentation pattern and upregulated expressions of Bax and p53 genes. The bioactive fraction was not toxic to human peripheral lymphocytes. HPLC, ESI-MS and GC-MS analysis of CF4 fraction indicated the presence of the compound hexadecanoic acid which might be responsible for the observed anti-cancer activity of $C$. minima. The methanol extract of $C$. minima exhibited anti-angiogenic effects on chick embryos.

Conclusion: It can be concluded that fraction, CF4, from C. minima is a promising source of an anti-cancer lead molecule.
\end{abstract}

Keywords: Angiogenesis, Apoptosis, Bax, Caspase, Chnoospora minima, p53 expression

\section{Background}

Cancer is a major challenge for humans throughout the world, being the second leading cause of death [1]. Cancer affects all age groups, genders, organs and tissues. Despite the advancements in the technology to diagnose and treat this disease, the mortality rate is very high among the affected people. The current treatment modalities of chemotherapy, surgery and radiotherapy are not efficient enough due to their significant side effects and unequal responses. Search for novel and efficient compounds from natural sources thus becomes very important in cancer management. Many molecules have been isolated from natural sources like plants/microorganisms which are being used as anti-cancer agents.
The marine environment with its enormous undiscovered compounds is an attractive source for bioactive compounds. Already, more than 20,000 compounds have been isolated from marine invertebrates. Marine algae comprise one of the fascinating groups of organisms that provide us a large window of opportunity to find novel compounds, owing to their diverse subspecies and variety of unknown, unimaginable molecules which can be used in research against cancer. Many marine algae have been reported to possess anti-tumour activities [2-4]. To find an alternative therapy for cancer, the present research work is focussed to evaluate the brown marine alga, named Chnoospora minima, which comes under the phaeophycean group of marine algae.

\footnotetext{
* Correspondence: kn.varalakshmi@jainuniversity.ac.in

Department of Biotechnology, School of Sciences, Jain (Deemed-to-be-

University), \#18/3, 9thMain, 3rd Block, Jayanagar, Bangalore, Karnataka

560011, India
} 


\section{Methods}

Collection of algal sample and preparation of extracts Marine algal sample was collected from Gulf of Mannar, south east coast of India (Long N 916.313 Lat E 79 00.073) Rameshwaram in the state of Tamilnadu. The sample was identified and authenticated as Chnoospora minima. Samples were washed with tap water, rinsed with distilled water for 3-4 times and allowed to dry under the shade. Dried samples were powdered in an electric mixer. Ten grammes of the sample was extracted with methanol using a soxhlet apparatus. Extracts were filtered using Whatman filter paper and concentrated in a rotary evaporator under reduced pressure.

\section{Purification of methanol extract by thin-layer chromatography (TLC)}

The methanol extract of C. minima (2 g) was partially purified by preparative TLC using commercially available Silica gel-coated chromatography sheets $(50 \times 20$ cm size, Merck), following standard methods [5].

\section{HPLC analysis of fraction CF4}

The partially purified fraction CF4 was purified by running the sample in a semi-preparative HPLC (LC-20 AD plus Detector, Shimadzu, Japan) connected to a system with LabSolutions software. The pumps (pump A and pump B) were used to pass the pressurized liquid solvent (water to methanol) along with the sample. Pump A was always maintained as water (default) and pump B was set as methanol. The fractions from the sample were separated based on the gradient applied in the system as shown in Table 1.

When the TLC-purified sample $(2 \mu \mathrm{L})$ was injected into the analytical column $(\mathrm{C} 18,5 \mu \mathrm{M}$ : dimension $4.6 \times$ $250 \mathrm{~mm}$ ), at a flow rate of $0.5 \mathrm{~mL} / \mathrm{min}$, the sample was separated into different fractions at different retention times. To collect the separated fractions from the sample mixtures, preparatory column was used. Hundred microlitres of injection volume were used in the preparatory column $(5 \mu \mathrm{M}, \mathrm{C} 18: 10 \times 50 \mathrm{~mm}$ dimensions $)$ with a flow rate of $1.2 \mathrm{~mL} / \mathrm{min}$ and total run was for $25 \mathrm{~min}$.

Table 1 Separation of samples based on the gradient applied in the HPLC programme

\begin{tabular}{llll}
\hline Time $(\mathrm{min})$ & Module & Command & Value (\%) \\
\hline 0.01 & Pumps & Pump B conc & 10 \\
2.00 & Pumps & Pump B conc & 10 \\
6.00 & Pumps & Pump B conc & 90 \\
10.00 & Pumps & Pump B conc & 90 \\
13.00 & Pumps & Pump B conc & 10 \\
20.00 & Pumps & Pump B conc & 10 \\
25.00 & Controller & Stop & \\
\hline
\end{tabular}

\section{ESI-MS analysis}

The major fractions separated through HPLC were subjected to QTOF Mass spectrometer ESI-QUAD-TOF (Bruker Impact HD, USA) at Indian Institute of Science (IISc, Bengaluru). Spectra were acquired at a maximum rate of $50 \mathrm{~Hz}$.

\section{GC-MS analysis}

The bioactive fraction of $C$. minima (CF4) was subjected to GC-MS analysis at Central Silk Technological Research Institute, Bangalore. The system is equipped with HP-5MS capillary column of $30 \mathrm{~mm} \times 0.25 \mathrm{~mm}$ and $0.25 \mathrm{~mm}$ of $1 \mathrm{~mm}$ thickness with $70 \mathrm{eV}$ of ionization energy. Helium was used as the carrier gas at a constant flow rate of $1 \mathrm{~mL} / \mathrm{min}$. One microlitre of the sample was injected into the GC-MS system, the injector port and detector temperature maintained at $280{ }^{\circ} \mathrm{C}$. The initial temperature was $50^{\circ} \mathrm{C}$ for $3 \mathrm{~min}$, then increased to $280^{\circ} \mathrm{C}$ and held for $2 \mathrm{~min}$. The resulting GC-MS peaks of unknown compounds were analysed and were compared with the database present in the MS library and other anti-cancer compound databases.

\section{Cell lines and culture conditions}

The breast cancer cell line MCF-7, cervical cancer cell line HeLa and liver cancer cell line HepG2 were procured from National Centre for Cell Sciences (NCCS), Pune. They were grown in minimal essential medium (MEM, HiMedia, India) containing $10 \%$ foetal bovine serum, $1000 \mathrm{U} / \mathrm{mL}$ penicillin, $100 \mu \mathrm{g} / \mathrm{mL}$ streptomycin and $\mathrm{pH} 7.4$ in $25 \mathrm{~cm}^{2}$ culture flasks. The flasks were incubated at $37^{\circ} \mathrm{C}$ in a $\mathrm{CO}_{2}$ Incubator (Thermofisher, USA).

\section{MTT Assay}

Exponentially growing cells were plated in 96-well plates at a density of $3 \times 10^{3}$ cells $/ \mathrm{mL}$ in $100 \mu \mathrm{L}$ of culture medium and were allowed to adhere for $16 \mathrm{~h}$ before treatment. Increasing concentrations of samples prepared in DMSO were added. Cytotoxicity was checked using 3-(4,5-dimethylthiazol-2-yl)-2,5-diphenyltetrazolium bromide (MTT) assay as per the standard protocol [6]. Each experiment was performed in triplicates.

\section{Viability by trypan blue staining}

Trypan blue staining solution was prepared at $0.4 \%$ concentration in phosphate buffer saline (PBS). The cells, $48 \mathrm{~h}$ after treatment with sample, were harvested by trypsinization and resuspended in $1 \mathrm{~mL}$ of PBS. Equal volumes of the dye and the cell suspension were thoroughly mixed in a sterile vial. The stained cells were observed under a microscope and counted using a haemocytometer [7]. 


\section{Cytotoxicity assessment by LDH assay}

The cytotoxicity was analysed by using Cytoscan ${ }^{\mathrm{Tm}} \mathrm{LDH}$ Assay method (G-Biosciences, India, kit \#786-210) [8]. In this method the cytosolic enzyme lactate dehydrogenase (LDH) was measured in the cancer cells after treatment with the sample. The enzymatic reaction results in the conversion of iodonitrotetrazolium (INT) to redcoloured formazan. The reduction of INT was measured quantitatively at $490 \mathrm{~nm}$ over a defined time period. The percentage cytotoxicity was calculated using the formula:

Cytotoxicity $(\%)=O . D_{490}$ of sample - O.D $_{490}$ of blank/O.D $D_{490}$ of positive control $\times 100$

\section{Caspase-3, 7 and 10 activity assay}

The activity of caspases (caspase-3, 7 and 10) was assessed in the cancer cells after sample treatment using the Caspase Colorimetric Assay Kit (G Biosciences, India, kit \# 786-205A). The assay was performed following the manufacturer's instructions.

\section{DNA fragmentation analysis}

Extract treated or untreated cells were harvested by trypsinization and centrifugation. For DNA fragmentation analysis, cellular DNA was extracted using the Blood and Cell Culture Mini DNA kit as per the manufacturer's instructions (Bangalore Genei, India). The DNA was visualized by ethidium bromide staining after agarose gel electrophoresis [9].

\section{Flow cytometry for cell cycle analysis Propidium iodide staining}

The cells were treated with the sample for $48 \mathrm{~h}$. The adherent cells were harvested by trypsinization and washed with serum-containing media. To fix the cells, $0.3 \mathrm{~mL}$ of cell suspension was taken in a vial and $0.7 \mathrm{~mL}$ of chilled $100 \%$ ethanol was added and overnight stored at $4{ }^{\circ} \mathrm{C}$. The cells were centrifuged at $2500 \mathrm{rpm}$ and washed twice with PBS prior to staining. Appropriate quantity of RNase (final concentration of $0.2-0.5 \mathrm{mg} / \mathrm{mL}$ ) was added and incubated at $37^{\circ} \mathrm{C}$ for $20 \mathrm{~min}$. To the cell suspension, PI stock stain solution (to get a final concentration of $40 \mu \mathrm{g} / \mathrm{mL}$ ) was added and incubated in the dark for $10 \mathrm{~min}$. The cells were scored by FACScan flow cytometer $(488 \mathrm{~nm})$ and the data were analysed using MACS Quant analyser [10].

\section{Bax and $\mathrm{p} 53$ expression studies by quantitative real-time PCR (qRTPCR)}

The cells $\left(2 \times 10^{6}\right.$ cells $\left./ \mathrm{mL}\right)$ were treated with $50 \mu \mathrm{g} / \mathrm{mL}$ of the bioactive fraction (CF4) for $48 \mathrm{~h}$. The cells were harvested by trypsinization followed by centrifugation at $1000 \mathrm{rpm}$ for $10 \mathrm{~min}$. Total RNA was extracted from the cell pellet according to the instruction given in the kit manual. After RNA isolation, the concentration and purity of RNA were assessed using a spectrophotometer (Sartorius, Germany). The purity of RNA was confirmed with an absorbance ratio at 260 and $280 \mathrm{~nm}$ (A260/ A280) between 1.8 and 2.2. For reverse transcription, cDNA was first synthesized from RNA using cDNA synthesizer provided in the kit. The cDNA was confirmed by performing PCR for actin gene (housekeeping gene) and it was analysed by $2 \%$ agarose gel electrophoresis. The sample was run in applied Biosystem one-step real-time PCR using SYBR Green Chemistry kit (Sensifast SYBR HiRoxkit, Bioline, USA) according to the procedure given in the instruction manual. The qRTPCR conditions were started with an initial denaturation at $95^{\circ} \mathrm{C}$ for $10 \mathrm{~min}$ and continued with 40 cycles of $15 \mathrm{~s}$ at $95^{\circ} \mathrm{C}$, annealing at $60^{\circ} \mathrm{C}$ for $30 \mathrm{~s}$ and extension at $72^{\circ} \mathrm{C}$ for $30 \mathrm{~s}$ using the specific primers for p53 and Bax genes (Table 2). $\beta$-actin was used as the housekeeping gene.

The results were analyzed by calculating the relative quantification $(\mathrm{RQ})$ values both in calibrator and treated sample using qbase plus software 13. To calculate the expression of a target gene (TG) relative to the EC, the comparative Ct $(\Delta \Delta \mathrm{Ct})$ method 148 (Step one Software v2.2.2) was used as per the following equation:

$\Delta \Delta \mathrm{Ct}=(\mathrm{Ct}$ target gene $)-(\mathrm{Ct} \mathrm{EC})-(\mathrm{Ct}$ target gene $)-(\mathrm{Ct}$ EC) test sample calibrator.

The $\Delta \Delta \mathrm{Ct}$ values will be converted to a linear form using the formula: $E-\Delta \Delta C \mathrm{t}$

$\Delta \mathrm{Ct}=$ Average $\mathrm{Ct}$ of test sample - Average $\mathrm{Ct}$ of calibrator.

The $\Delta \mathrm{Ct}$ values will be converted to a linear form using the formula: $E-\Delta \mathrm{Ct}$, where $E=$ amplification efficiency.

\section{Assay for anti-angiogenesis on chick embryos}

Inhibition of blood vessel formation was analysed by the modified chick chorioallantoic membrane (CAM) assay [11]. Instead of using filter paper or silicone ring on the CAM layer, the sample was directly injected to 8-dayold chick embryos and its effect on the blood capillaries was checked after $72 \mathrm{~h}$. Fertilized chicken eggs were collected from Veterinary College, Hebbal, Bangalore, and were maintained in $\mathrm{CO}_{2}$ incubator at $55-60 \%$ humidity. Fertilized eggs (8th-12th day) were used for the study. The eggs were wiped with $70 \%$ ethanol, a mark was made below the air space of the eggs and a hole was made on the mark using an egg puncher under sterile

Table 2 Forward and reverse primer sequences used for the study

\begin{tabular}{lll}
\hline Gene & Forward primer (5'-3') & Reverse primer (5'-3') \\
\hline p53 & AGAGTCTATAGGCCCACCCC & GCTCGACGCTAGGATCTGAC \\
Bax & TTTGCTTCAGGGTTCATCC & CAGTTGAAGTTGCCGTCAGA \\
B-actin & GGACTTCGAGCAAGAGATGG & AGCACTGTGTTGGCGTACAG \\
\hline
\end{tabular}


conditions. The needle of the syringe was carefully placed at $45^{\circ}$ angle into the allantoic cavity. A hundred microlitres of different concentrations of the samples $(0.5,1.0$ and $2.0 \mathrm{mg} / \mathrm{mL})$ was directly injected to the eggs. A hundred microlitres of DMSO in phosphate buffered saline (1:9) was used as the negative control and eggs without any injections were used as normal controls. After injection, the hole was sealed with parafilm wax to avoid contamination from external sources. The eggs were returned to the incubator for $72 \mathrm{~h}$. The anti-angiogenesis activity was examined both macroscopically and microscopically after $72 \mathrm{~h}$ of treatment. The number of eggs used for the study was six and all the experiments were carried out thrice.

\section{Macroscopic observation}

The egg shell was opened and the effect was visualized under the dissection microscope. The quantification and inhibitory effect of extracts on the blood vessels were calculated manually by counting the number of blood vessels in control as well as in the treated group, using the following formula [12].

Inhibition of blood vessel $(\%)=$ No. of blood vessel in control - No. of blood vessel in treated/number of blood vessels in control $\times 100$

\section{Histopathological studies}

Slides were prepared from different layers of control and treated chick embryos for histopathology and were stained with haematoxylin and eosin stain. The stained slides were examined under a binocular microscope, (Olympus, Germany 5X 541) and were photographed. Slides were scored for (1) structure of blood vessel mainly highlighting endothelial cells, (2) number and frequency of blood vessels and (3) membrane integrity.

\section{Statistical analysis}

The experiments were carried out in triplicates and the results were expressed as mean \pm standard error. Data from the experiments were analysed using one-way analysis of variance (ANOVA) with the help of GraphPad

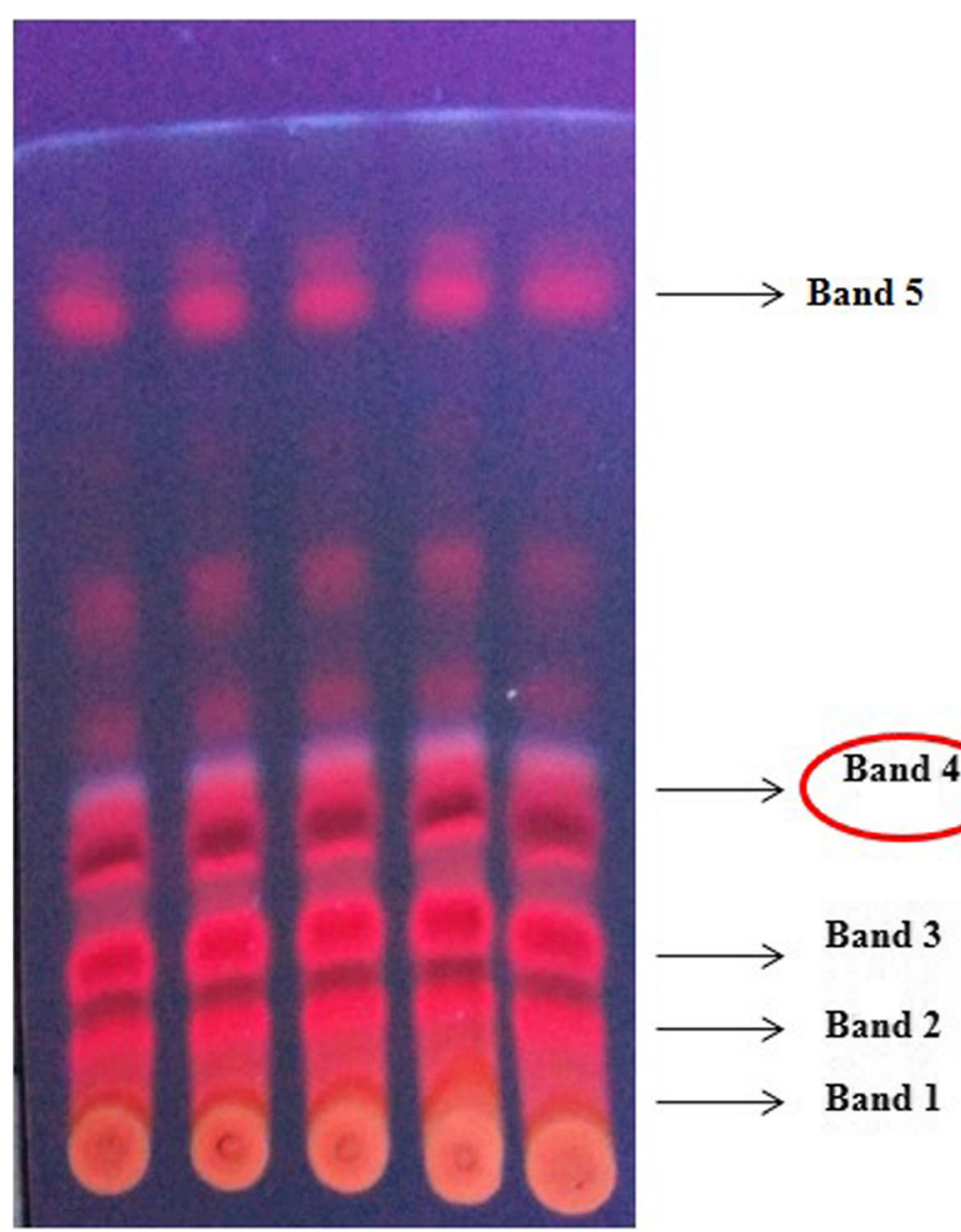

Fig. 1 TLC separated fractions of C. minima as observed under UV transilluminator 
Prism 6.0 software. Using Duncan's multiple range test (DMRT), the sample means were compared. Differences were considered significant at $p<0.05$.

\section{Results}

\section{Purification of C. minima extract by TLC}

The partial purification of the methanol extract of $C$. minima by TLC using the solvent combination of dichloromethane and chloroform (3:7) resulted in five different bands (Fig. 1)

\section{HPLC purification}

Out of the five fractions separated by TLC, the bioactive fraction CF4 was purified by HPLC method and the resulting chromatogram showed maximum peak at retention times (RT) 0.4-0.9 min and 6.5-6.6 min (Fig. 2a).

\section{ESI-MS analysis}

When the HPLC eluted fractions were further analysed by mass spectrometry, maximum spectral intensity was observed for the eluent with an $\mathrm{m} / \mathrm{z}$ value of 274.3 (Fig. $2 \mathrm{~b}$ ).

\section{GC-MS Analysis}

As per GC-MS results, the compounds present in the bioactive fraction are hexadecanoic acid, undecane, ethanol 2- phenoxy,7.7.9.9.11.11-hexamethyl-3.6.8.10.12.15-hexaoxa7.9.11.trisilaheptadecane, cyclotetrasiloxane, octamethyl-, diethyl pthalate, hexasiloxane, tetradecamethyl-, 16octadecenoic acid, methyl ester and bis (2-ethylhexyl) phthalate. The maximum peak was obtained at 18.1 retention time and the compound laid on that peak was hexadecanoic acid (Fig. 3a, b).

\section{Cytotoxicity of $C$. minima to different cancer cell lines}

When the methanol extract from $C$. minima was screened for cytotoxicity by MTT assay on MCF-7, HeLa and HepG2 cancer cell lines at two different concentrations $(50 \mu \mathrm{g} / \mathrm{mL}$ and $100 \mu \mathrm{g} / \mathrm{mL})$, it was found that the extract was effective against all the cell lines and maximum effect was on MCF-7 cell line with a viability of $63 \%$ at $100 \mu \mathrm{g} / \mathrm{mL}$ (Fig. 4a). The screening of all 5 TLC separated fractions of $C$. minima extract indicated the 4th fraction (CF4) as having highest cytotoxicity to MCF-7 cells with $48 \%$ viability and was identified as the bioactive fraction (Fig. 4b). When cancer cells were treated with $50 \mu \mathrm{g} / \mathrm{mL}$ of CF4, the percentage viability of the treated MCF-7 cells was $48 \%$, HeLa was $54 \%$ and HepG2 was $55 \%$ (Fig. 4c). The $\mathrm{IC}_{50}$ concentration of CF4 fraction was $37 \mu \mathrm{g} / \mathrm{mL}$ in the case of MCF-7 cells, $50 \mu \mathrm{g} / \mathrm{mL}$ on HeLa cells and $45 \mu \mathrm{g} / \mathrm{mL}$ on HepG2 cells
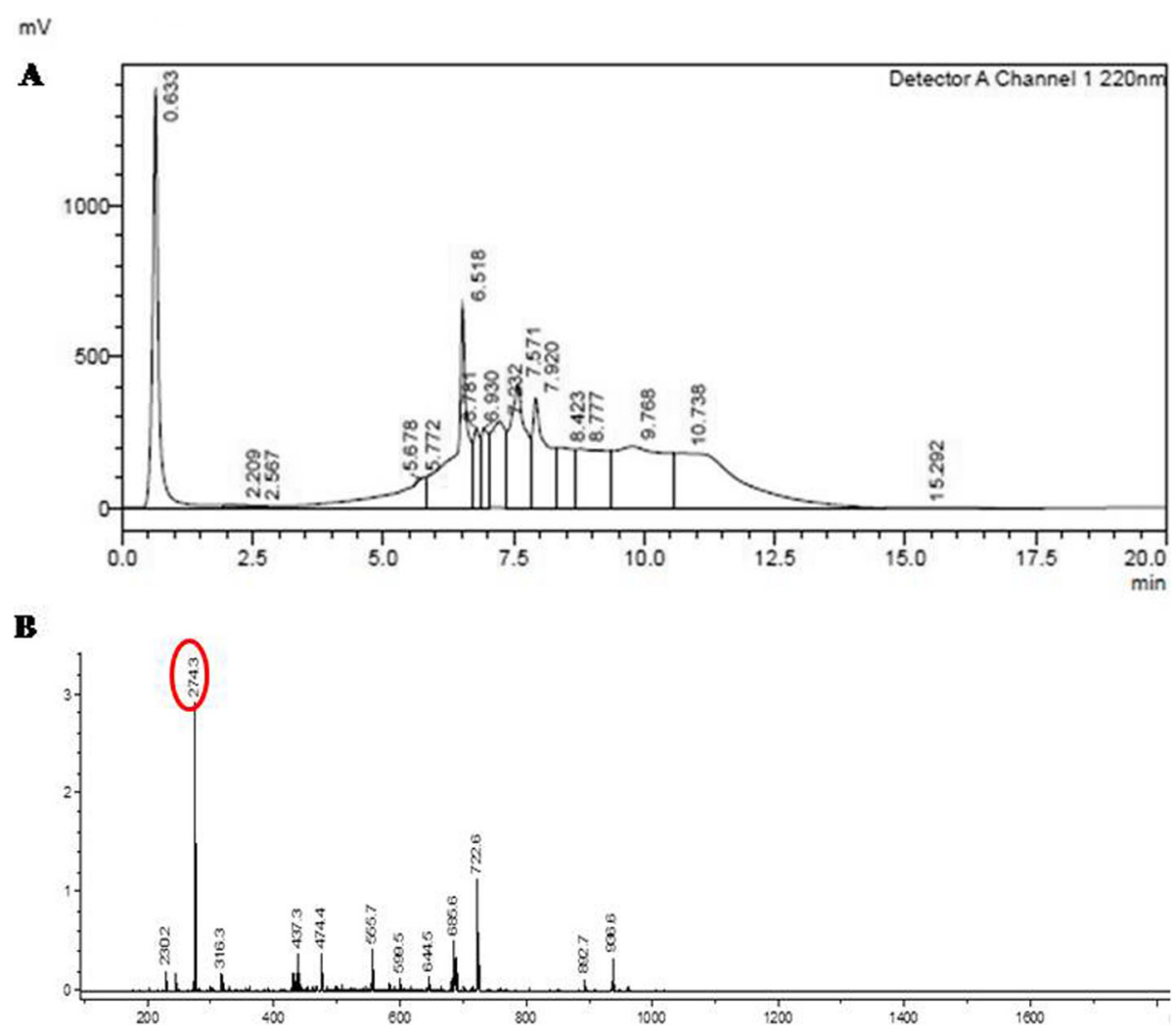

Fig. 2 Analysis of CF4 fraction by HPLC. a The HPLC chromatogram of the fraction CF4. b Mass spectrum of the HPLC purified eluent at RT 6.5-6.6 min 


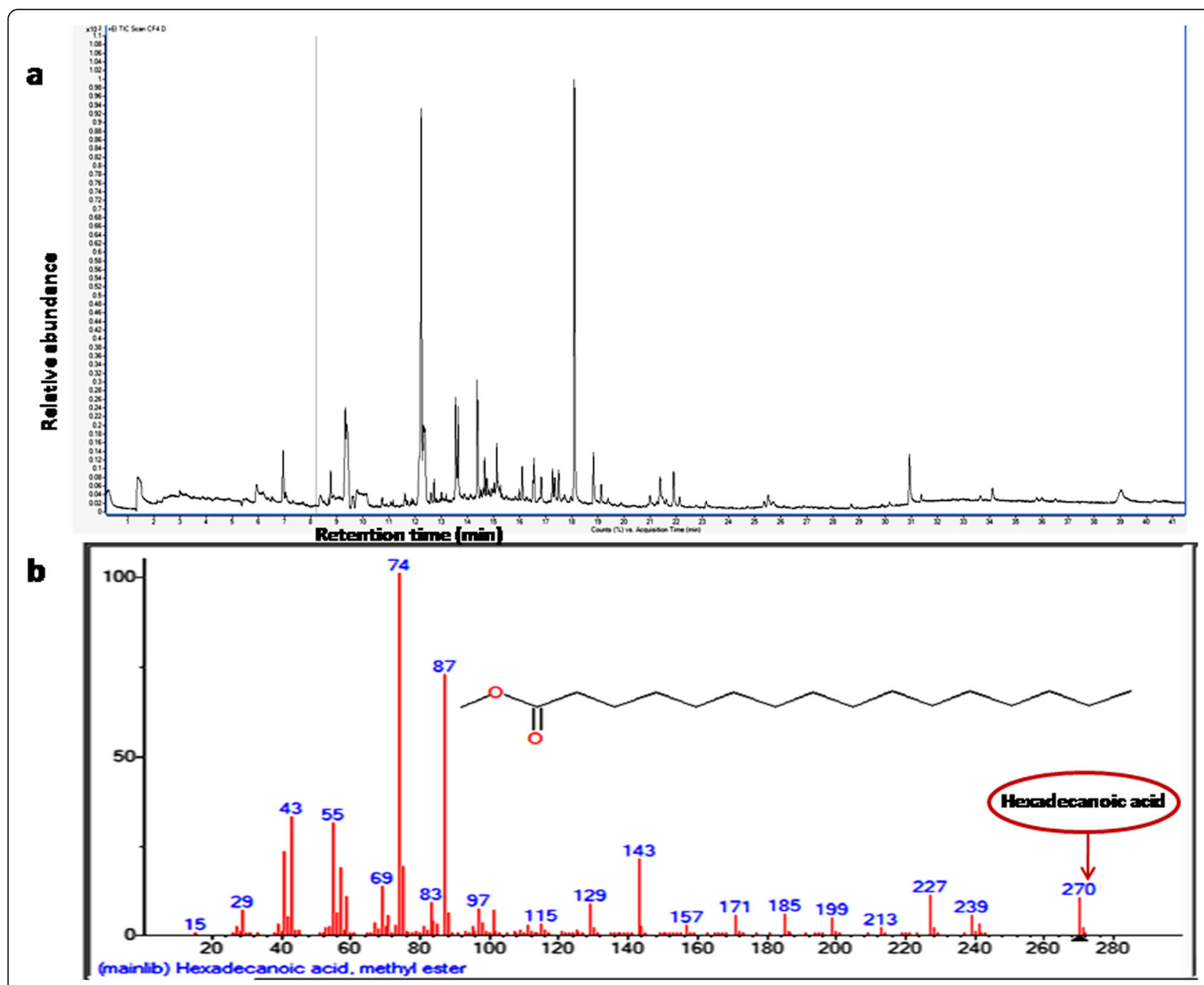

Fig. 3 GC-MS analysis of fraction CF4. a Gas chromatogram of bioactive fraction CF4. b Mass spectra of CF4 along with structure of hexadecanoic acid

for $72 \mathrm{~h}$ of treatment. The effect was found to be dose- and time-dependent, thus indicating the antiproliferative property of CF4. When fraction CF4 was tested on normal human peripheral lymphocytes, the percentage viability of lymphocytes was found to be 100 at all treatment periods, indicating the safety of CF4 to normal cells.

\section{Cell concentration and cell viability}

The cancer cells treated by CF4 were found to be affected at a concentration $50 \mu \mathrm{g} / \mathrm{mL}$ with a cell concentration of $7.2 \times 10^{6}$ cells $/ \mathrm{mL}, 3.15 \times 10^{6}$ cells $/ \mathrm{mL}$ and $5.8 \times 10^{6}$ cells $/ \mathrm{mL}$ for HeLa, MCF-7 and HepG2 cells, respectively (Fig. 5a). These cell concentrations were significantly lesser than that of the control cells. The percentage viability of CF4-treated normal lymphocytes was almost close to 100 .

\section{LDH cytotoxicity}

The maximum release of LDH was observed for CF4 treatment on MCF-7 cells with a cytotoxicity of $42.75 \%$ (Fig. 5b), followed by $31.63 \%$ in HeLa cells and $11.24 \%$ in HepG2cells. The effect of CF4 was cell line-specific. No cytotoxicity was caused by CF4 to normal human lymphocytes.

\section{Caspase-3, 7 and 10 activities}

When caspase enzyme activity was analysed in the treated cancer cells, we found a gradual increase of activity in MCF-7, HeLa and HepG2 cells (Fig. 6). The activity was 49.59\% higher in MCF-7, 40\% higher in HeLa and 7.3\% higher in HepG2 cells as compared to the control cells.

\section{DNA fragmentation}

When the DNA extracted from the treated and untreated cancer cells were run in agarose gel, it was found 

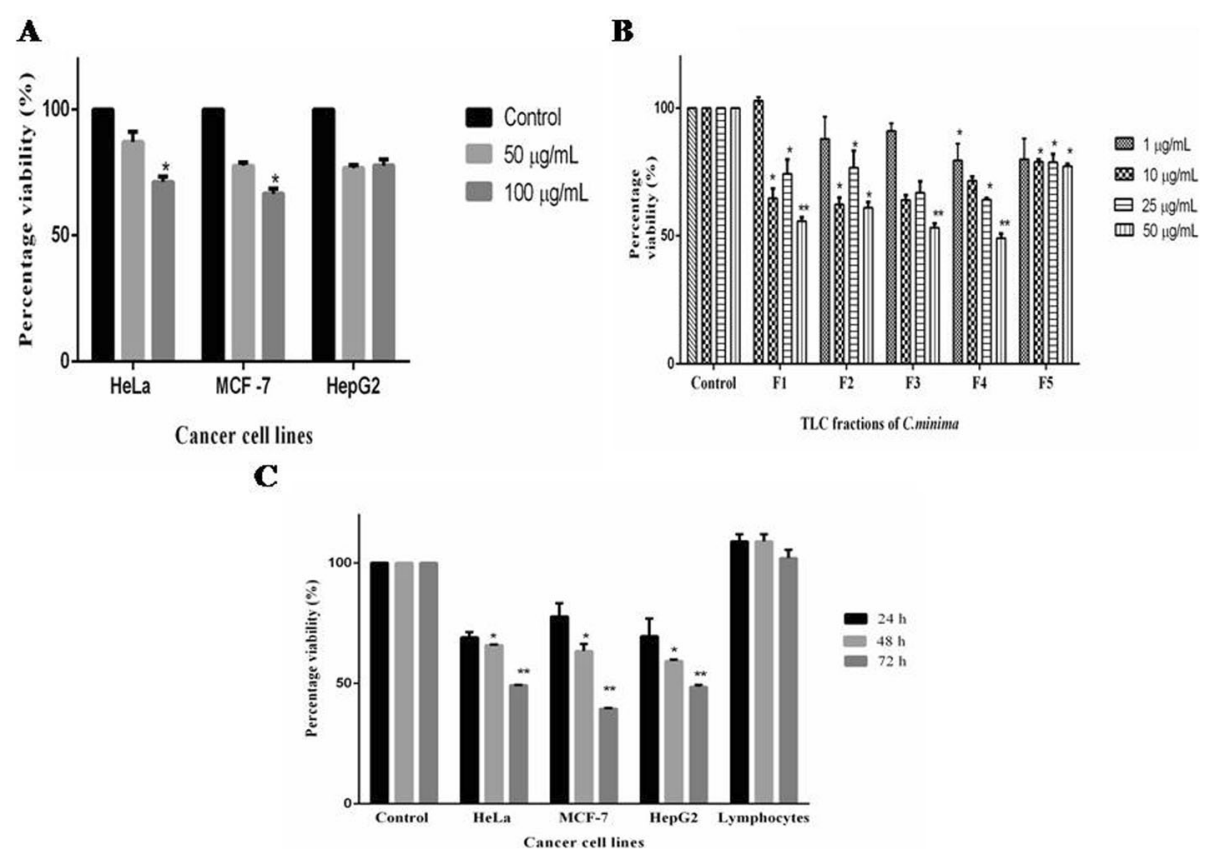

Fig. 4 Effect of C. minima extract and CF4 fraction on human cancer cell lines. a Percentage viability of HeLa, MCF-7 and HepG2 cells treated with C. minima. $\mathbf{b}$ Effect of TLC fractions of C. minima on MCF-7 cells for 48 h. c Effect of CF4 on HeLa, MCF-7, Hep G2 and lymphocyte cells for 24,48 and $72 \mathrm{~h}$. The values are expressed as mean \pm SE. An asterisk denotes significance at $p<0.05$ and two asterisks denotes significance at $p$ $<0.01$

that the DNA was appearing as a smear due to fragmentation in the treated cancer cells (MCF-7, HepG2 and HeLa) as compared to the control groups (Fig. 7).

\section{Cell cycle of CF4-treated cancer cells}

When the cells were analysed through flow cytometry after $48 \mathrm{~h}$ of treatment with CF4, we found that (Fig. 8) in MCF-7 cells, a significant proportion (35.7\%) of cells were in sub G0/G1 phase, indicating apoptosis. In the case of HeLa cells, G2/M phase arrest was seen with $85.9 \%$ of cells in this phase as compared to the control group where only $19.3 \%$ cells were in G2/M phase. In the case of HepG2 cells, a higher proportion of apoptotic cells $(43.0 \%)$ were found in sub G0/G1 phase. S phase cells increased from 13.5 to $17.3 \%$ along with a decrease of $\mathrm{G} 2 / \mathrm{M}$ phase cells from 13.5 to $9.7 \%$.

\section{Relative expression of Bax and p53 genes}

When the expression pattern of Bax and p53 inMCF7 cells treated with the sample were checked by qRTPCR, we found 3.2-fold higher expression of Bax gene than that of the untreated control cells (Fig. 9a). The expression of p53 was also found to be upregulated (2.7-folds higher) than that of the untreated control cells (Fig. 9b).

\section{Anti-angiogenesis effect \\ Macroscopic observation}

When different concentrations $(0.5,1.0$ and $2.0 \mathrm{mg} / \mathrm{mL})$ of C. minima extract were injected to 8-day-old chick embryos, anti-angiogenic property was evidenced after $72 \mathrm{~h}$ of treatment. At $2 \mathrm{mg} / \mathrm{mL}$ concentration of treatment, we found significant inhibition of blood capillaries, while moderate inhibition of blood vessels was seen at 0.5 and $1 \mathrm{mg} / \mathrm{mL}$ concentrations (Fig. 10a, b).

\section{Histopathology observation of chick embryos}

The anti-angiogenic potential of C. minima was observed by studying the histological preparations of the blood vessel formed in the chick embryos. From Fig. 11, it can be seen that the control embryos had thick-walled endothelial cells and the number of blood vessels was higher. In the case of treated embryos, significant reduction of large and small blood vessels along with the presence of thin endothelial cells was seen. The antiangiogenic effect of $C$. minima was found to be dosedependent.

\section{Discussion}

One way to control the proliferation of cancer growth is by inducing cell death in the cancer cells. Hence, drugs should be designed in order to induce cell death either by apoptosis or necrosis. Marine algae comprise one of the important sources of natural bioactive compounds 


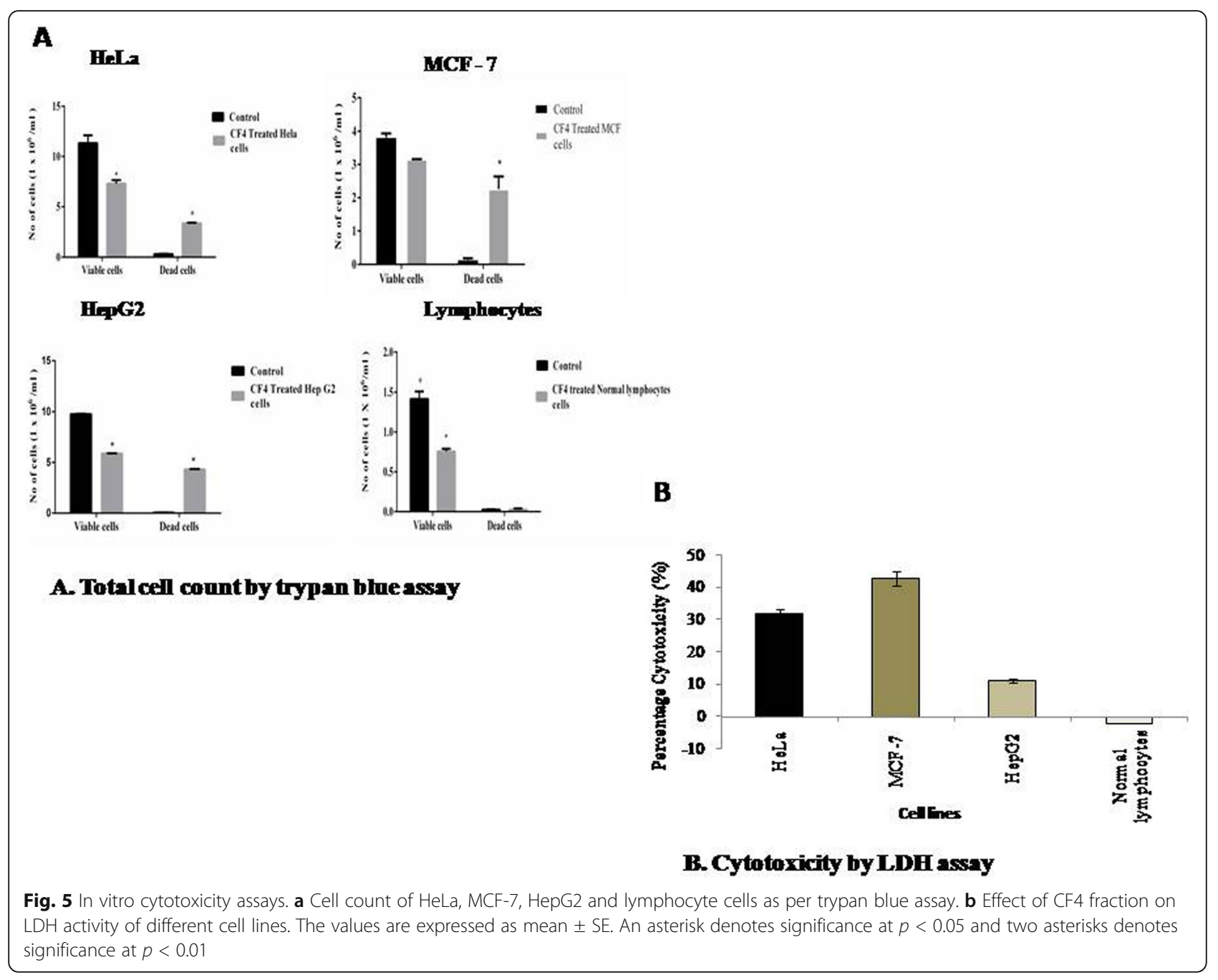

\section{MCF-7}

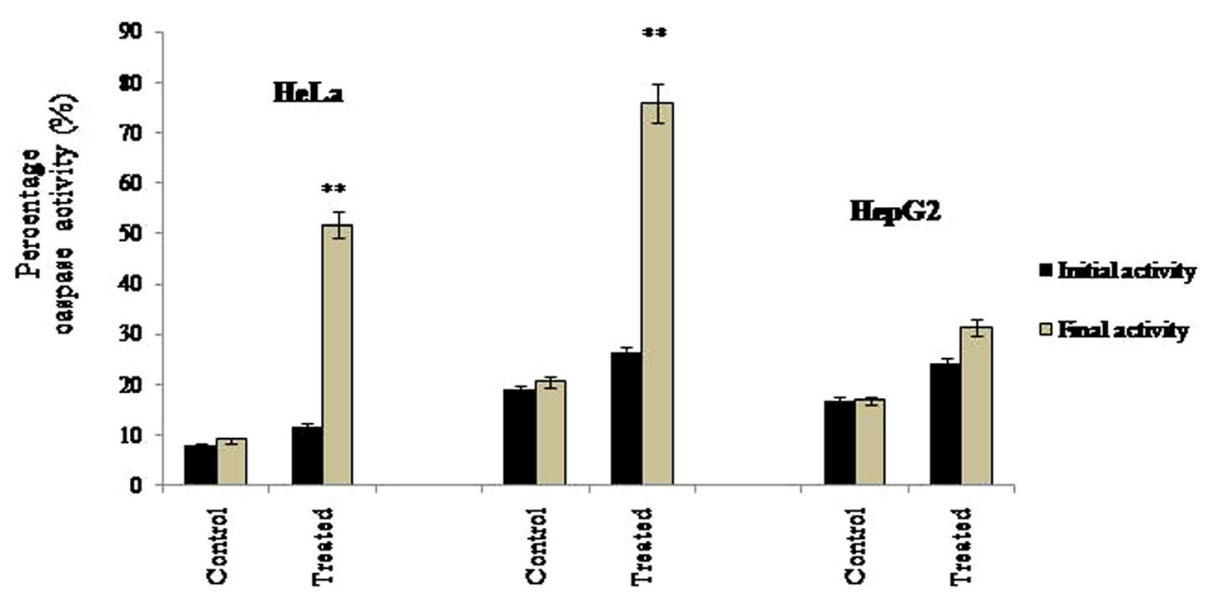

Cancer cell lines

Fig. 6 Caspase activity of the cancer cells. Caspase-3, 7 and 10 activity of CF4-treated HeLa, MCF-7 and HepG2 cells. The values are expressed as mean \pm SE. An asterisk denotes significance at $p<0.05$ and two asterisks denotes significance at $p<0.01$ 


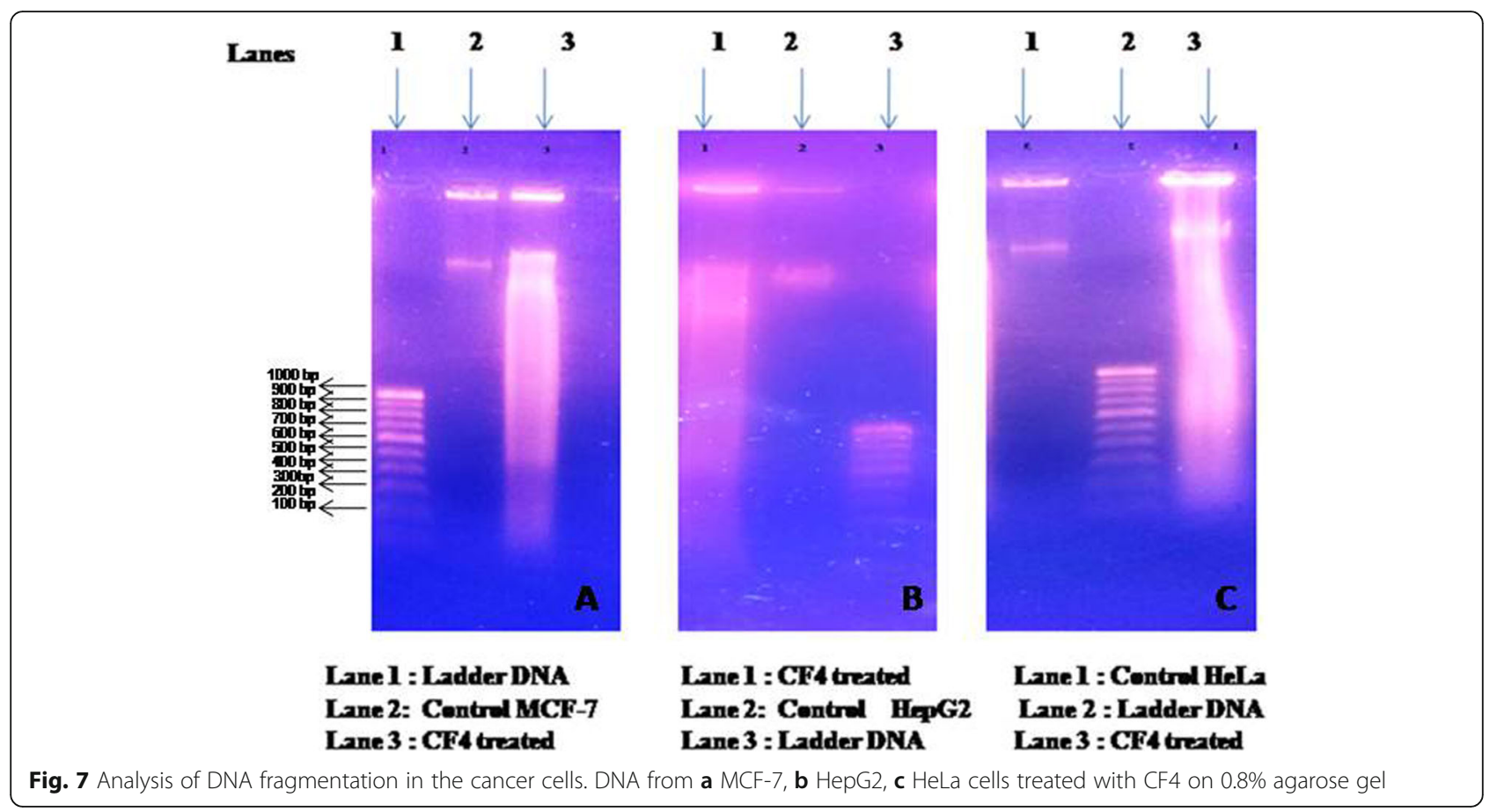

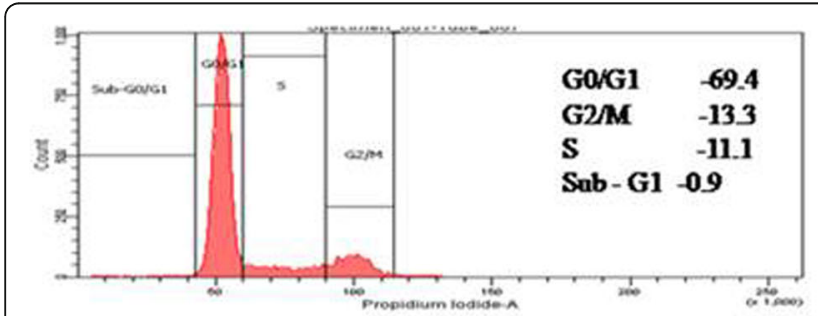

A. i) Centrad HeI a cells

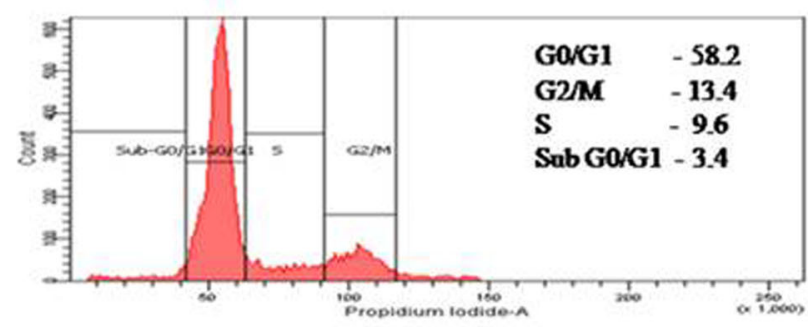

B.j) Control MCF-7

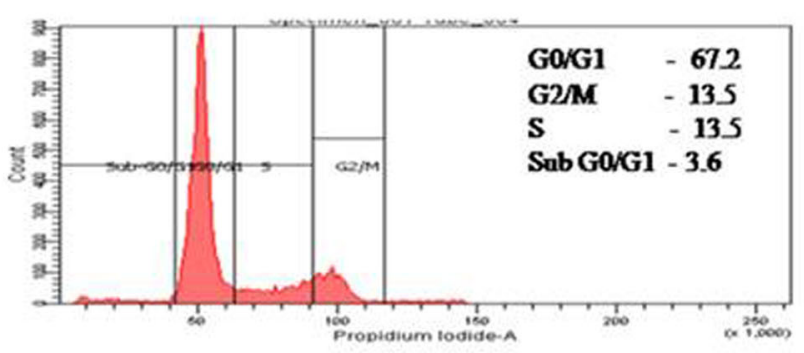

Ci) Control HepG2 cells

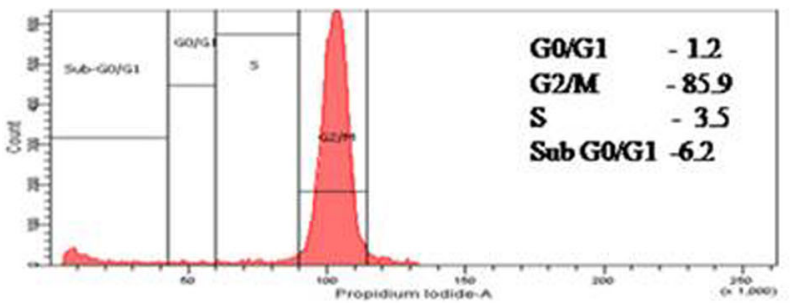

i) Treated HeI a cells

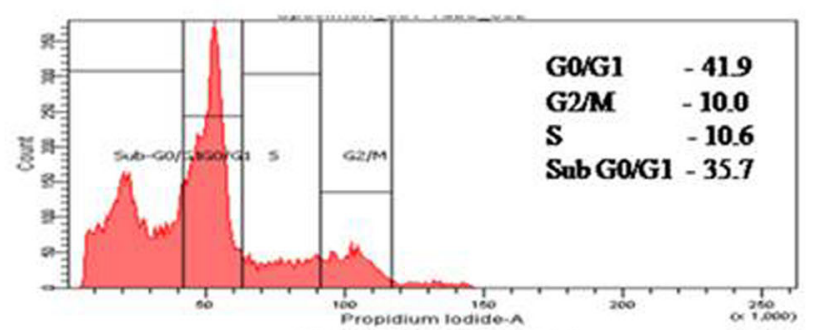

i) Treated MCF-7 cells

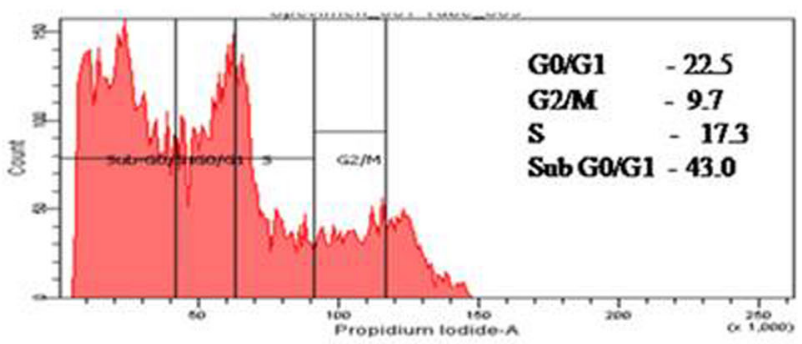

b) Treated HepG2 cells

Fig. 8 Flow cytometry analysis of cell cycle by PI staining. a (i) Control HeLa cells and (ii) treated HeLa cells. b (i) Control MCF-7 cells and (ii) treated MCF-7 cells. c (i) Control HepG2 cells and (ii) treated HepG2 cells 

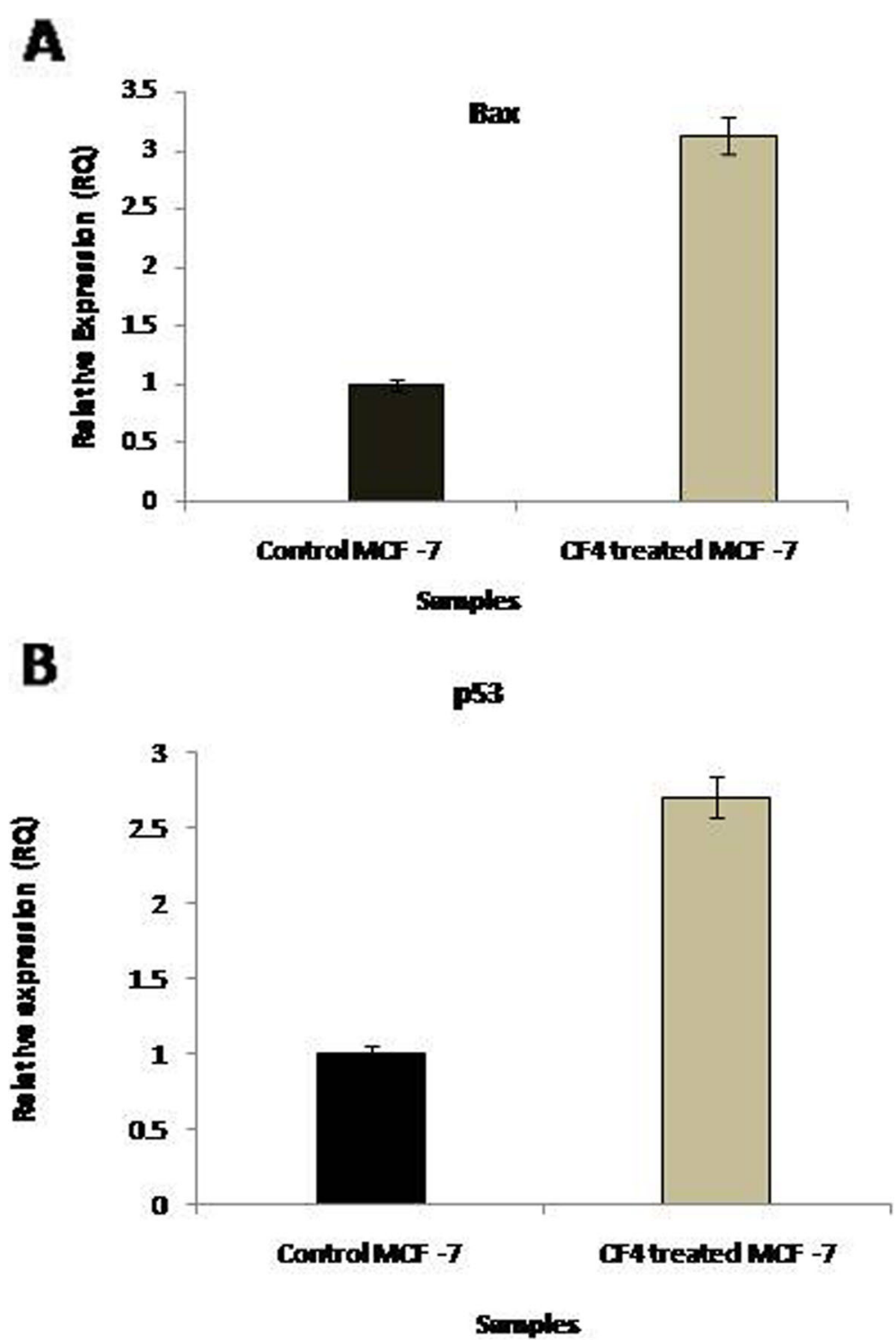

Fig. 9 Analysis of gene expression by GRTPCR. a Relative expression of Bax gene in treated and untreated cells. b Relative expression of p53 gene in treated and untreated cells

$[13,14]$. In the current study, the brown marine alga, Chnoospora minima, demonstrated significant antiproliferative activity against the tested cancer cell lines. In the mitochondrial activity assay, the bioactive fraction CF4 demonstrated an effective response against the proliferation of cells. The $\mathrm{IC}_{50}$ concentration of this fraction was $37 \mu \mathrm{g} / \mathrm{mL}$ on MCF-7, followed by $50 \mu \mathrm{g} / \mathrm{mL}$ on $\mathrm{HeLa}$ and $45 \mu \mathrm{g} / \mathrm{mL}$ on HepG2 cells for $72 \mathrm{~h}$. In another study [15], the seaweed Chnoospora implexa was reported as to inhibit the growth of MCF-7 cell lines. The $\mathrm{LC}_{50}$ value (lethal concentration) of C. implexa, $U$. lactuca and C. hornemanni seaweeds were $125 \mu \mathrm{g} / \mathrm{mL}$. In one more study, the fractions of brown algae such as Sargassum swartzii, Cystoseira myrica and Colpomenia sinuosa had anti-proliferative effects against cancer cell lines. Here, the $\mathrm{IC}_{50}$ values were greater than that of methotrexate, the positive control [16]. From these reports, we came to the conclusion that $C$. minima has effective cytotoxicity to the cancer cells at a lower concentration $(50 \mu \mathrm{g} / \mathrm{mL})$. TLC purified fraction showed higher activities than the whole extracts. This could be due to the presence of lesser quantities of bioactive components in whole extracts and these compounds becoming concentrated during TLC fractionation [17]. The mechanism of action of the bioactive fraction CF4 in inhibiting cancer cell growth appears to be through the induction of apoptosis as well as by preventing angiogenesis. 


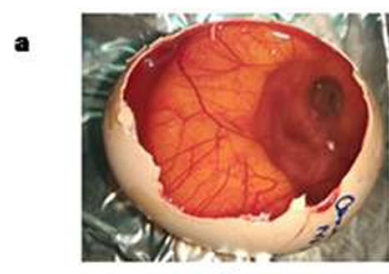

A

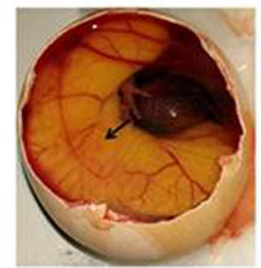

c

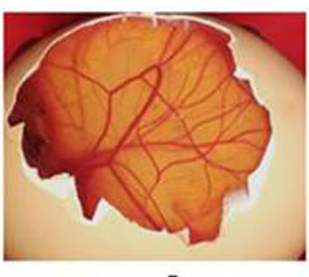

B

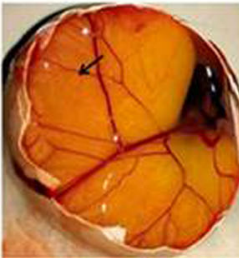

D

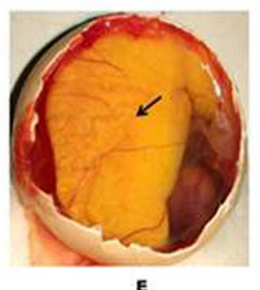

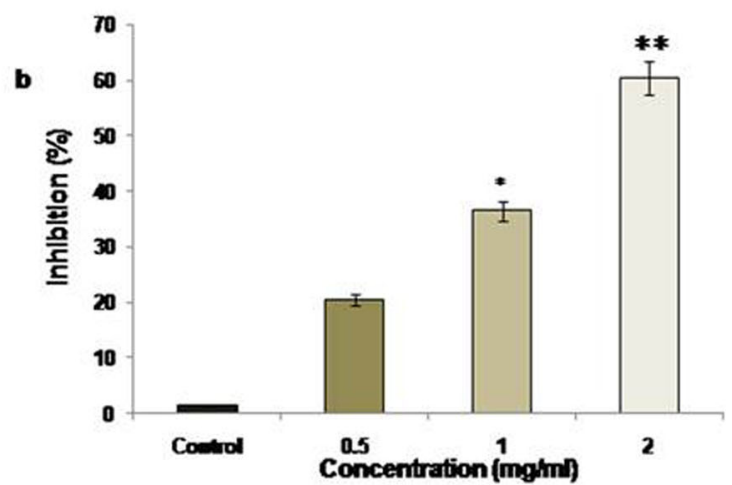

Fig. 10 Anti-angiogenesis effect of C. minima on chick embryos. a (A) Control chick embryo, (B) DMSO treated control, (C) 0.5 mg/mL treated, (D) $1.0 \mathrm{mg} / \mathrm{mL}$ treated, (E) $2.0 \mathrm{mg} / \mathrm{mL}$ treated. Arrow indicates the inhibition of blood vessel branch points $\mathbf{b}$ Percentage Inhibition of blood vessels in 8-day-old chick embryos treated with C. minima. The values are expressed as mean $\pm \mathrm{SE}$. An asterisk denotes significance at $p<0.05$ and two asterisks denotes significance at $p<0.01$

Caspases are a family of protease enzymes involved in playing crucial roles such as initiation and execution of programmed cell death. Accordingly, we found an increase in the activity of caspase-3, 7 and 10 in C. minima treated cancer cells giving an evidence for the ongoing apoptotic process in these cells. Correlating well with this event, DNA fragmentation was also observed in the treated HeLa, MCF-7 and HepG2 cells indicating that CF4 is causing the cancer cell death through caspase activation and inducing apoptosis. The initiation of DNA fragmentation can be related to the activation of caspase- 3 activity [18].

The growth of tumour and its metastasis are mainly dependent on angiogenesis as suggested by Folkman [19] that the inhibition of angiogenesis could be a valuable approach for cancer therapy. The use of animal models for the study of angiogenesis is an important tool for screening new agents that might inhibit or activate angiogenesis. The chick embryo assay is a widely used method for in vivo study to analyse the antiangiogenesis activity. Through our study on chick embryos, it was found that C. minima extract efficiently inhibited the formation of new blood capillaries from the pre-existing blood vessels [20]. The formation of capillary plexus is accompanied by decrease in CAM thickness and reduction in mesenchymal cells [21]. Namvar et al. [22] reported that the marine brown alga, Sargassum muticum, has anti-angiogenic effect. Ganesan et al. [23] reported the anti-angiogenesis effect of the siphonaxanthin from the green seaweed. In our study, $C$. minima extract suppressed angiogenesis by inhibiting the migration of mesodermal blood vessels to the basement membrane leading to the decrease in the capillary plexus and thereby reducing the thickness of CAM layer.

A strong evidence for apoptosis being induced by the bioactive compound from $C$. minima was provided by the results of qRT-PCR analysis of Bax and p53 genes. Generally, cancer cells proliferate due to the higher expression of the anti-apoptotic genes and downregulating the pro-apoptotic genes and thereby evading apoptosis. In this study, the expression of pro-apoptotic Bax gene was upregulated in the treated cells indicating that the cells are undergoing apoptosis due to Bax overexpression. In the same cells, the tumour suppressor gene, p53, was 


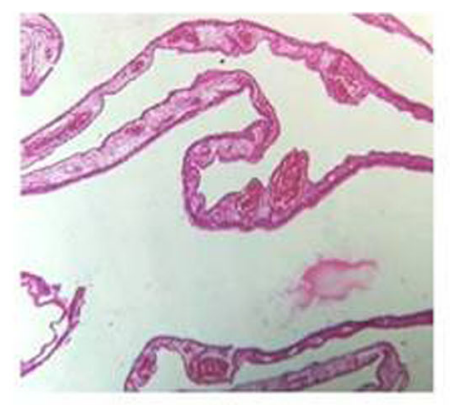

A

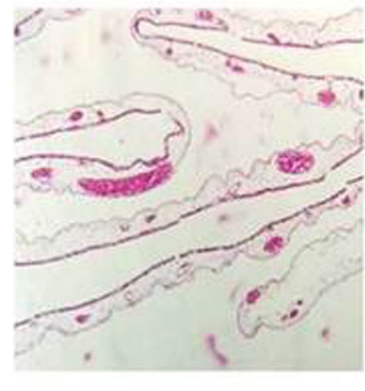

C

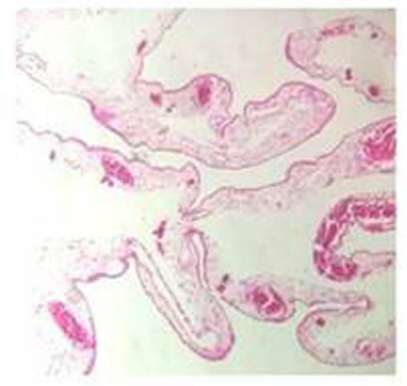

D

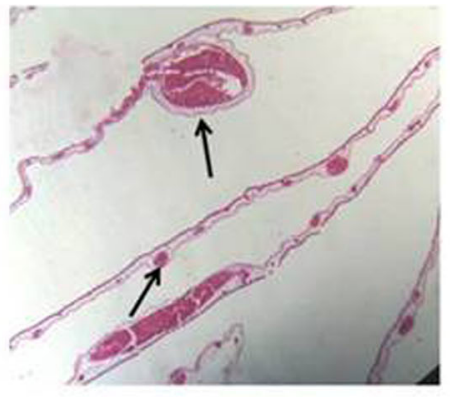

B

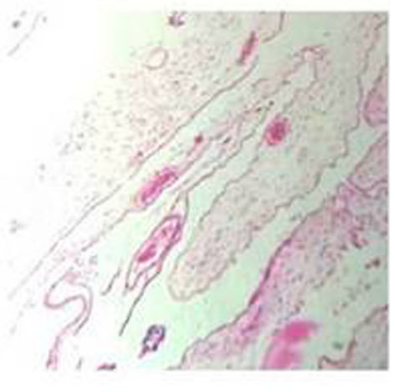

E

Fig. 11 Histopathological examination of chick embryos at $\times 40$ magnification. a Control CAM. b DMSO treated control. c $0.5 \mathrm{mg} / \mathrm{mL}$ treated. d $1 \mathrm{mg} / \mathrm{mL}$ treated. e $2 \mathrm{mg} / \mathrm{mL}$ treated. Black arrow indicates the presence of large and small blood vessels

also found to be overexpressed. This p53 gene plays a vital role in inducing cell death after DNA damage and genomic instability, as it is a nuclear transcription activator of the Bax gene [24] which interacts with Bcl-2 to enhance outer mitochondrial membrane permeabilization. The increased expression of p53 might be responsible for the increase in the Bax to Bcl-2 ratio, resulting in the release of cytochrome $\mathrm{c}$, the activation of caspases and ultimately apoptosis $[25,26]$. This was strongly supported by the bioactive fraction CF4 induced apoptosis in the MCF7 cells where a 2.7 -fold increase in the mRNA level of p53 in the treated group was observed when compared to the control cells.

Due to the promising anticancer potential demonstrated by the TLC-purified fraction CF4, it was further purified by HPLC and the major fraction was further characterized through ESI-MS analysis. The maximum spectral intensity was observed at $274.3 \mathrm{~m} / \mathrm{z}$ ratio. The molecular ion peak obtained from MS data was found to be closely related to the compound hexadecanoic acid $(\mathrm{m} / \mathrm{z}$ ratio 270$)$ separated out from the GC-MS results. The molecular ion peaks for methylpalmitate was at 270 $\mathrm{m} / \mathrm{z}$ ratio [27]. Characterization of CF4 through GC-MS studies also indicated hexadecanoic acid as a major component in CF4. All these results collectively suggest that the major compound present in C. minima as an analogue of the fatty acid hexadecanoic acid. Hexadecanoic acid is a saturated fatty acid, synonyms of palmitic acid and is known to have anti-microbial, anti-oxidant activities and known to reduce the risk of coronary artery diseases [28]. In the present study, we found that the bioactive compound in C. minima has antiproliferative activity against the cancer cell lines at $50 \mu \mathrm{g} / \mathrm{mL}$ concentration. Relevant to this study [29], there is a report that palmitic acid from the marine red alga Amphiroa zonata as a cytotoxic substance at $50 \mu \mathrm{g} /$ $\mathrm{mL}$ concentration to human leukemic cells. Nhexadecanoic acid extracted from the leaves of Kigelia pinnata demonstrated anti-cancer activity [30]. Palmitic acid was reported as to be present in higher amounts in some marine red algae [31-38]. The previous studies on C. minima reported its anti-inflammatory and antioxidant activities. According to a previous report [39], polysaccharides from C. minima (SLBS11P) had high anti-oxidant activities. To the best of our knowledge, the anti-cancer potential of C. minima is being reported for the first time through the outcomes of the current study.

\section{Conclusion}

In summary, it can be concluded that the bioactive fraction from the brown macroalga, C. minima, is efficient in suppressing the growth of the cancer cells and at the same time is non-toxic to normal human peripheral lymphocytes. It also demonstrated anti-angiogenic activity on chick embryo model, providing the alternative source for cancer therapy. Presence of hexadecanoic acid along with other bioactive compounds appears as the main reason for the anti-cancer property of C. minima. 
To the best of our knowledge, this study on $C$. minima is the first published report about its antiproliferative activity. Further in vivo studies need to be carried out in order to find the efficiency of hexadecanoic and its analogues as anti-cancer compounds.

\begin{abstract}
Abbreviations
Hela: Cervical cancer cell line; MCF-7: Breast cancer cell line; HepG2: Liver cancer cell line; TLC: Thin-layer chromatography; MTT: 3-(4,5-Dimethylthiazol2-yl)-2,5-diphenyltetrazolium bromide dye; HPLC: High-performance liquid chromatography; GC-MS: Gas chromatography-mass spectrometry; ESIMS: Electro-spray ionization mass spectrometry; qRTPCR: Quantitative realtime PCR; MARS: Marine Algal Research Station; CAM: Chickchrioallantoic membrane; Pl: Propidium iodide
\end{abstract}

\section{Acknowledgements}

The authors are thankful to Jain (Deemed-to-be University) for providing the fellowship and for the infrastructural facilities to carry out the work. The authors are grateful to Dr. K. Eswaran, Principal scientist in Marine Algal Research station for the identification of seaweed for the work. The authors are grateful to Mr. M.A. Joseph, Scientist at Central Silk Technological Research Institute, Bengaluru, for providing GC-MS facility and analysis of the samples for our work in his institute.

The authors acknowledge the support of Dr. Byregowda, Director in IAH \& VB, Hebbal, Bengaluru, for providing the facilities for chick embryo studies in his laboratory.

The authors are also thankful to Dr.Sugana Rao, Professor at Veterinary College, Hebbal, Bengaluru, for helping in analysing the histopathlogical slides.

\section{Authors' contributions}

VKN and SP: designed the study of the work. SP: a research scholar who carried out the sample collection, analysis and interpretation of data and writing of the manuscript. VKN: guiding the student to design the work, analysis and interpretation of data and editing of the manuscript. All authors read and approved the final manuscript.

\section{Funding}

Not applicable

\section{Availability of data and materials}

The data that support the findings of this study are available from the corresponding author (VKN), upon reasonable request. A voucher specimen of this marine alga has been deposited in the Jain University herbarium with the number- JUBTMA01

Ethics approval and consent to participate

Not applicable

\section{Consent for publication}

Not applicable

\section{Competing interests}

The authors declare that they have no competing interests.

Received: 2 December 2019 Accepted: 18 May 2020

Published online: 05 June 2020

\section{References}

1. Aggarwal BB, Danda D, Gupta S, Gehlot P (2009)Models for prevention and treatment of cancer: problems vs. promises. BiochemPharmacol78(9):10831094. https://doi.org/10.1016/j.bcp.2009.05.027

2. Zhuang $\mathrm{H}$, Itoh T, Mizuno, Ito $\mathrm{H}$ (1999) Antitumor active fucoidan from the brown seaweed, umitoranoo (Sargassumthunbergii). Biosci Biotechnol Biochem 59(4):563-567. https://doi.org/10.1271/bbb.59.563

3. Coombe DR, Parish CR, Ramshaw IA, Snowden JM (1987) Analysis of the inhibition of tumour metastasis by sulphated polysaccharides. Int J Cancer 39 (1):82-88. https://doi.org/10.1002/ijc.2910390115.
4. Vischer P, Buddecke E (1991) Different action of heparin and fucoidan on arterial smooth muscle cell proliferation and thrombospondin and fibronectin metabolism. Eur J Cell Biol 56(2):407-414

5. Kirchner JG, Miller JM, Keller GJ (1951) Separation and identification of some terpenes by new chromatographic technique. Anal Chem 23 (3):420-425. https://doi.org/10.1021/ac60051a008

6. Mosmann T (1983) Rapid colorimetric assay for cellular growth and survival: application to proliferation and cytotoxicity assays. J Immunol Methods 65(1-2): 55-63. https://doi.org/10.1016/0022-1759(83)90303-4

7. Strober W (2001) Trypan blue exclusion test of cell viability. Current protocols in immunology, John Wiley \& Sons 21(1):77. https://doi.org/10. 1002/0471142735.ima03bs21

8. Weyermann J, Lochmann D, Zimmer A (2005) A practical note on the use of cytotoxicity assays. Int J Pharm 288(2):369-376. https://doi.org/10.1016/j. ijpharm.2004.09.018.

9. Shidoji Y, Ogawa H (2004) Natural occurrence of cancer-preventive geranylgeranoic acid in medicinal herbs. J Lipid Res 45:1092-1103. https:// doi.org/10.1 194/jlr.M300502-JLR200

10. Pazarowski P, and Darzynkiewicz Z (2004) Analysis of cell cycle by flow cytometry. Methods Mol Bio 281: 301-311. https://doi.org/10.1385/1-59259811-0:301

11. RibattiD RL, Nico B, Bertossi M (1987) Effects of exogenous heparin on the vasculogenesis of the chorioallantoic membrane. Acta Anat 130:257-263

12. Hardeep S, Tuli S, Sandhu ,Anil KS, Puneet G (2014) Anti angiogenic activity of the extracted fermentation broth of an entomopathogenic fungus Cordycepsmillitaris. Int J Pharm Sci 6(7):1-6. https://doi.org/10.1186/2045824X-4-8.

13. Riley RD, Ridley G, Williams K, Altman DG, Hayden J (2007) Prognosis research: toward evidence-based results and a Cochrane methods group. J ClinEpidemiol 60 (8): 863-865. https://doi.org/10.1016/j.jclinepi.2007.02.004.

14. Riley RD, Lambert PC, Abo-Zaid G (2010) Meta-analysis of individual participant data: rationale, conduct, and reporting. BMJ 340:c221. https://doi. org/10.1136/bmj.c221.

15. Shyamala V, AnaghaK TN (2013) In vitro antioxidant and antiproliferative activities of macro algae against MCF-7 cell line. J Pharm Biomed Sci 32: 1413-1424

16. Khanavi M, Nabavi M, Sadatin, Ardekani SM, Sohrabipour J, Mohammed S, Nabavi, Ghael P, Ostad N (2010) Cytotoxic activity of some marine brown algae against cancer cell lines. Biol Res 43(1):31-37. https://doi.org/S071697602010000100005

17. Babayi H, Kolo I, Okogun JI, ljah UJJ (2004) The antimicrobial activities of methanolic extracts of Eucalyptus camaldulensis and Terminaliacatappa against some pathogenic microorganisms. Biochem 16 (2):106-111. https:// doi.org/10.4314/biokem.v16i2.32578.

18. Walters J, Pop C, Scott FL (2009) A constitutively active and uninhibitable caspase3 zymogen efficiently induces apoptosis. Biochem J 424(3):335-345. https://doi.org/10.1042/BJ20090825

19. Folkman J (1971) Tumor angiogenesis: therapeutic implications. N Engl J Med 285:1182-1186. https://doi.org/10.1056/NEJM197111182852108.

20. García-Caballero M, Cañedo L, Fernández-Medarde A, Medina MÁ, Quesada AR (2014) The marine fungal metabolite, AD0157, inhibits angiogenesis by targeting the Akt signalling pathway. Mar Drugs. 12(1):279-299. https://doi. org/10.3390/md12010279.

21. Melkonian G, Munoz N, Chung J, Tong C, Marr R, Talbot P (2002) Capillary plexus development in the day five to day six chick chorio-allantoic membrane is inhibited by cytochalasin D and suramin. J Exp Zool. 292:241254. https://doi.org/10.1002/jez.10014.

22. Namvar F, Mohamad R, Baharara J, Balanejad SZ, Fargahi F, Rahman HS (2013) Anti oxidant, anti proliferative and anti-angiogenesis effect of poly phenol-rich seaweed (Sargassum muticum). Biomed Res Int 2013: 604787. https://doi.org/10.1155/2013/604787.

23. Ganesan P, Matsubara K, Ohkubo T et al., (2010) Anti-angiogenic effect of siphonaxanthin from green alga, Codium fragile. Phytomedicine 17(14): 1140-1144. https://doi.org/10.1016/j.phymed.2010.05.005.

24. Miyashita T, and Reed JC (1995)Tumor Suppressor p53 is a Direct transcriptional activator of the human Bax gene. Cell80:293-299. https://doi. org/10.1016/0092-8674(95)90412-3.

25. Rassouli FB, Matin MM, Iranshahi M, Bahrami AR, Behravan J, Mollazadeh S, and Neshati V (2011) Investigating the enhancement of cisplatin cytotoxicity by combination with mogoltacin on 5637 cells. Toxicol In Vitro 25:469-474. https://doi.org/10.1016/j.tiv.2010.11.015. 
26. Luo G et al (2008) Thesphingolipid long-chain base-Pkh1/2-Ypk1/2 signaling pathway regulates eisosome assembly and turnover. J Biol Chem 283(16): 10433-10444. https://doi.org/10.1074/jbc.M709972200.

27. Basumatary S, Deka DC (2012) Identification of fattyacid methyl esters in biodisel from Pithecellobiummonodelphum seed oil. Der Chemica Sinica 3(6):1384-1393

28. Bodoprost J, Rosemeyer $\mathrm{H}$ (2007) Analysis of phenacylester derivatives of fatty acids from human skin surface sebum by reversed-phase HPLC: chromatographic mobility as a function of physico-chemical properties. Int J Mol Sci 8(11):1111-1124. https://doi.org/10.3390/18111111.

29. Harada H, Yamashita U, Kurihara H, Fukushi E, Kawabata J, Kamei Y (2002) Antitumor activity of palmitic acid found as a selective cytotoxic substance in a marine red alga. Anticancer Res 22(5):2587-2590

30. Ravi L, Krishnan K (2017) Cytotoxic potential of N-hexadeconic acid extracted from Kigelia pinnata leaves. Asian J Cell Biol 12(1):20-27. https:// doi.org/10.3923/ajcb.2017.20.27.

31. Baghel RS, Kumari P, Reddy CRK, Jha B (2014) Growth, pigments, and biochemical composition of marine red alga Gracilaria crassa. J Appl Phycol 26(5):2143-2150. https://doi.org/10.1007/s10811-014-0250-5.

32. Guaratini T, Lopes NP,Marinho-soriano E, Colepicolo O, Pinto E (2012) Antioxidant activity and chemical composition of the nonpolar fraction of Gracilaria domingensis (Kützing) Sonder ex Dickie and Gracilaria birdiae (Plastino\& Oliveira). Rev Bras Farmacogn 22(4):724-729. https://doi.org/10 1590/50102-695X2012005000063

33. Hornicar VB, Parfene G, Tyagi AK, Gottardi D, Dinica R, Guerzoni ME, Bahrim $G$ (2014) Extraction and characterization of volatile compounds and fatty acids from red and green macroalgae from the Romanian Black Sea in order to obtain valuable bioadditives and biopreservatives. J Appl Phycol 26:551-559. https://doi.org/10.1007/s10811-013-0053-0

34. Kang JY, Benliro IMP, Lee IJ, Choi JY, Joo J, Choi YS, Hwang DS Hong NYK (2014) Viability, fatty acid composition, and structure of the coralline alga Corallina pilulifera. Bot Sci 92 (1):103-109. https://doi.org/10.17129/botsci.24

35. Kendel M, Wielgoz-collin G, Bertrand S, Roussakis C, Bourgounon N, Bedoux G (2015) Lipid composition, fatty acids and sterols in the seaweeds U/va armoricana, and Solieriachordalis from Brittany (France): an analysis from nutritional, chemotaxonomic, and antiproliferative activity perspectives. Mar Drugs 13(9):5606-5628. https://doi.org/10.3390/md13095606.

36. Rodrigues D, Freitas AC, Pereira L, Rochasantos TAP, Vasconcelos MW, Roriz M, Rodriguez-alcala LM, Gomes AMP, Duarte AC (2015) Chemical composition of red, brown and green macroalgae from Buarcos bay in Central West coast of Portugal. Food Chem 183: 197-207. https://doi.org/10. 1016/j.foodchem.2015.03.057

37. Santos SAO, Vilela C, Freire CSR, Abreu MH, Rocha SM, Silvestre AJD (2015) Chlorophyta and Rhodophytamacroalgae: A source of health promoting phytochemicals. Food Chem 183:122-128. https://doi.org/10.1016/j. foodchem.2015.03.006

38. Shimid M, Guiheneuf F, Stengel DB (2014) Fatty acid contents and profiles of 16 macroalgae collected from the Irish Coast at two seasons. J Appl Phycol 26(1): 451-463. https://doi.org/10.1007/s10811-013-0132-2.

39. Fernando IPS, Sanjeewa KKA, Samarakoon KW, Lee WW, Kim HS, Kang N Ranasinghe P, Lee HS, Jeon YJ (2017) A Fucoidan fraction purified from Chnoospora minima; a potential inhibitor of LPS-induced inflammatory responses. Int J Biol Macromol 104: 1185-1193. https://doi.org/10.1016/j. ijbiomac.2017.07.031.

\section{Publisher's Note}

Springer Nature remains neutral with regard to jurisdictional claims in published maps and institutional affiliations.

\section{Submit your manuscript to a SpringerOpen ${ }^{\circ}$ journal and benefit from:}

- Convenient online submission

- Rigorous peer review

- Open access: articles freely available online

High visibility within the field

- Retaining the copyright to your article

Submit your next manuscript at $\boldsymbol{\sim}$ springeropen.com 